\title{
PRDX4 Gene
}

National Cancer Institute

\section{Source}

National Cancer Institute. PRDX4 Gene. NCI Thesaurus. Code C116654.

This gene plays a role in both cellular redox and nuclear factor NF-kappa-B activity. 